\title{
Educational Technology in Higher Education on Pandemic Covid-19 Experiences
}

\author{
Ismail Suardi Wekke \\ Institut Agama Islam Negeri (IAIN) Sorong, Indonesia \\ Asosiasi Dosen Insan Cita Indonesia, Indonesia \\ The Jusuf Kalla Research Center for Cultural Studies, Universitas Muslim Indonesia \\ iswekke@gmail.com \\ Muhammad Ihsan \\ Universitas Pendidikan Muhammadiyah Sorong, Indonesia \\ Muhammadihsanunimudasorong@gmail.com, \\ Muhammad Rusdi Rasyid \\ Institut Agama Islam Negeri (IAIN) Sorong, Indonesia \\ rusdipasca@gmail.com \\ Rudihartono Ismail \\ Universitas Amal Ilmiah Yapis Wamena, Indonesia \\ Rudihartonoismail6889@gmail.com \\ Muhammad Makbul \\ UIN Alauddin Makassar, Indonesia \\ makbulm013@gmail.com
}

\begin{abstract}
The educational technology is very important in the world of education because it can facilitate the process of learning activities both in the classroom and learning activities at home as it is now when learning online or online because of the covid-19 pandemic that spreads throughout the world, including in Indonesia. of learning and learning, the history of the development of educational technology and knowing the meaning of educational technology. The research method used is sourced from secondary data. Secondary data is data obtained from information or knowledge obtained indirectly, among others, includes official documents, books, and research results in the form of reports. The results of this study explain that educational technology has developed steadily where each stage in its development creates a new discovery that facilitates learning activities. The emergence of educational technology makes it easier for educators and students to learn independently and can create the latest innovations in the world of education so that a learning and learning innovation will emerge that makes educators and students able to learn easily and fun.
\end{abstract}

\section{Keywords:}

Education technology, covid-19

\section{Introduction}

Along with the times and followed by the development of science and technology must be utilized by all elements of society, including utilization in the world of education. The main purpose of utilizing technological developments is to improve the quality of education in Indonesia. National Education System Law No. 20 of 2003 in Chapter 1 Paragraph 1 has explained about the definition of education is a conscious and planned effort 
to create a learning atmosphere and learning process so that students actively develop their potential. Education is the most important thing for the life of all nations and countries in the world. Because education determines the progress of a country. (Machali, I. 2014)

The purpose of national education is to educate the nation's life and develop Indonesian people as a whole. National Education Goals in Law no. 20, 2003 Article 3, "Education functions to develop capabilities and shape the character and civilization of a dignified nation in the context of educating the nation's life, aiming at developing the potential of students to become human beings who believe and fear God Almighty, have noble character, are healthy, knowledgeable, capable, creative, independent, and become a democratic and responsible citizen". (Indonesia, Republic Act. "National education system." Jakarta: Directorate of General Secondary Education 2003).

According to Gagne in Priansa (2017: 130) states that learning media are various types of components in the learner's environment that can motivate students to learn. Learning media can also be understood as anything that can be used to convey messages from teachers to students or vice versa. (Tanjung, R., Ritonga, T., \& Siregar, EY 2021). so that it can stimulate the thoughts, feelings, and interests, as well as the attention of students so that the learning process can take place effectively and efficiently.

Seeing these conditions, cooperating with technology is a must, by integrating learning in higher education, it is hoped that the implementation of education can occur effectively, but these assumptions need to be studied from various points of view, including related to literature review in its implementation. Therefore, it becomes interesting to elaborate on the discussion related to educational technology in higher education

\section{Methods}

The method of this writing is library research which is a study used in collecting information and data with the help of various kinds of materials in the library such as documents, books, magazines, historical stories. While the source comes from secondary data. Secondary data is data obtained from information or knowledge obtained indirectly, including official documents, books, and research results in the form of reports.

\section{Results and Discussion 3.1 Study and Learning}

The revised 2013 curriculum (K-13 Revision) is the curriculum that applies in the Indonesian education system, the implementation of the 2013 curriculum begins in the 2016/2017 school year to replace the 2006 curriculum (Education Unit Level Curriculum) which is valid for approximately 6 years in Indonesia. Assessment of the curriculum must include aspects of compensation for attitudes (Attitude), aspects of skills (Skills), aspects of knowledge (Knowledge) as a whole and proportionally, in accordance with the core competencies that have been determined. Students are required to understand the material, be active in the discussion and presentation process and have high manners and discipline. The learning system of the revised 2013 curriculum is student centered, namely students who must be active in finding their own learning resources. Learning activities do not focus on the teacher as a source of learning but rather focus on students. The teacher is no longer the center of the learning process because the center of the learning process is the student, while the teacher is only a facilitator. Students can find their own learning resources that have been provided in the school library, the internet, from peers, the environment, and electronic media and print media. Teaching behavior and learning behavior are related to learning materials. Learning materials can be in the form of knowledge, moral values, art, religion, attitudes, and skills.

The relationship between teachers, students, and teaching materials is dynamic and complex. To achieve success in learning activities, there are several components that can support, namely the objective component, the material component, the teaching and learning strategy component, and the evaluation component. (Bahriani, 2020).

Each of these components are interrelated and influence each other. Learning is a system, which consists of various components that are interconnected with one another. The four learning components must be considered by the teacher in choosing the learning model and media used in learning activities.

\subsection{History of Educational Technology}

In the 1960s, educational technology became one of the studies that received a lot of attention in educational circles. Initially, educational technology was a continuation of the development of studies on the use of 
audiovisual, and learning programs in education. The study is essentially an attempt to solve human learning problems (Arifuddin, Wekke, \& Firdaus, 2019).

The solution taken through the study of educational technology is that solving learning problems needs to use appropriate approaches with a lot of functioning of the use of learning resources (learning resources). The development of educational technology studies produces various educational concepts and practices that use the media as a source of learning. (Mujahid, I., Minsih, M., Ghafur, WA, \& Wekke, IS 2019). Therefore, there is a perception that educational technology is the same as the media, even though the position of the media serves as a means to facilitate the delivery of information or learning materials. In terms of the education system, the position of educational technology serves to strengthen curriculum development, especially in its design and development, as well as its implementation. there is even an assumption that the curriculum is related to "what", while educational technology examines "how". In relation to learning, educational technology strengthens in engineering various ways and techniques from the design stage, development, utilization of various learning resources, implementation, and assessment of programs and learning outcomes. Based on the history of its development, the term educational technology began to be used since 1963, and was officially pledged by the Association of Educational and Communication Technology (AECT) since 1977, although sometimes there is overlapping the use of the term with learning technology. However, these two terms are still used in accordance with the considerations of the users. Finn (1965) revealed that in England and Canada the term educational technology is more commonly used, while in the United States the term learning technology is widely used. But sometimes the two terms are used simultaneously in the same activity. And recently the concept has developed that learning technology is more suitable for use in the context of teaching. (Mulyono, \& Wekke, 2018).

In addition to the history above, there are also historical stages of the development of educational technology in general, namely:

1. The first stage, educational technology is combined with the use of tools such as graphs, maps, symbols, models, specimens and concrete materials. Educational technology is a term used as a synonym for visual aids. This educational technology is the oldest educational technology but unfortunately there is no written evidence of the beginning of this technology being used. It is very possible that it has been used since the beginning of humans on earth.

2. The second stage of educational technology is associated with the electronic revolution with the introduction and formation of sophisticated hardware accompanied by supporting software. The use of various aids of projectors, tape recorders, radio and television brings revolutionary enlightenment in the educational scenario. Thus the concept of educational technology taken in this case is a sophisticated instrument and teaching material for the effective presentation of teaching materials.

3. The third stage of educational technology is related to the development of mass media which in turn led to a revolution in communication for instructional purposes. Computer Assisted Instruction (CAI) which was used for education since the 1950s also became popular during that era.

4. The fourth stage of educational technology is when educational technology is seen as a process of instruction (learning). The invention of programmed learning and programmed instruction gave a new dimension to educational technology. Self-learning systems built on self-instructional materials and teaching machines began to emerge.

5. The fifth stage of the development of educational technology is characterized and influenced by the concept of systems engineering or systems approach which focuses on language laboratories, teaching machines, programmed instruction, multimedia technology, and the use of computers in instruction. At this stage educational technology is a systematic way of designing, implementing, and evaluating the total teaching and learning process in terms of specific objectives based on research.

The use of information and communication technology to provide educational services has promising potential to improve learning outcomes. In Indonesia, more than 530,000 schools were closed in an effort to reduce the spread of the corona virus (COVID-19). This affects 68 million students from pre-school to college level and makes the need for effective EdTech even more pressing. (Musthan, \& Wekke, 2018). This situation forces a rapid and widespread increase in the use of EdTech in the country, which is expected to have a lasting effect on the market. (Tukwain, Fatimah, \& Wekke, 2018).

Edtech lanskap landscape surveyin Indonesia which we recently published reveal that the EdTech sector in Indonesia is catching up with global achievements. The survey noted the growth of local platforms such asHarukaedu (a platform that offers degrees in higher education online), Teacher's room (an interactive e-learning platform for students from kindergarten to grade 12 in Indonesia) and Competentby Squline (a tutoring platform for learning languages). However, in general, this sector is still just beginning to develop. 
The reluctance among some educational institutions, teachers and parents to adopt technology has changed as a result of the pandemic, as almost everyone now relies on online and distance education methods. We predict that the pandemic will accelerate the adoption of online learning methods and encourage educational institutions to use distance learning to strengthen resilience to future crises. (Taufik, \& Warsono, 2020).

Data from Google Trends shows that searches for the term "study from home" and similar terms experienced a sharp spike reflecting increased demand for online and distance education. Another indicator is the sharp increase in website traffic and application downloads of the leading EdTech platform since February 2020. EdTech's use of information and communication technology to provide educational services has promising potential to improve learning outcomes. In Indonesia, more than 530,000 schools were closed in an effort to reduce the spread of the corona virus (COVID-19). This affects 68 million students from pre-school to college level and makes the need for effective EdTech even more pressing. This situation forces a rapid and widespread increase in the use of EdTech in the country, which is expected to have a lasting effect on the market (Kristiawan, Yuniarsih, Fitria, \& Refika, 2019).

The growing demand for online learning is driving massive growth for Indonesia's leading EdTech platforms. Two of the most popular EdTech products offer learning management systems for teacher-student collaboration and online teaching management, as well as interactive classroom tools to host live and interactive learning sessions, such as G-Suite for Education, Microsoft for Education, Zoom, etc.

However, not all teaching participants can access EdTech, because the Indonesian education system is not ready to add learning online quickly. Many rural students lack connectivity, and many low-income students do not have access to the tools necessary to use EdTech tools. This is in contrast to low-tech options such as television: $95 \%$ of students accessed TV in the previous week (96.6\% in urban and $92.3 \%$ in rural) according to data fromNational Socio-economic Survey (SUSENAS) 2018 To help address issues related to equity in access, the Ministry of Education and Culture launched an education program called Study from Home on national television on April 13.

Despite increasing demand, the EdTech sector in Indonesia faces barriers to repeating the technological successes that have occurred in other sectors as well as in other countries. Constraints on the supply side include:

1. Difficult to access funding

2. High marginal costs, particularly for acquiring and retaining new customers

3. Lack of talented resources to develop and maintain products.

This is compounded by constraints on the demand side, including:

1. Low willingness to pay from school and parents

2. Lack of digital literacy, especially on the education provider side

3. Poor digital infrastructure, which limits connectivity in remote areas and download speeds throughout Indonesia.

Barriers to the development of learning technology in Indonesia include:

1. Lack of procurement of ICT infrastructure. The importance of modern learning using information and communication technology makes schools must have adequate infrastructure and facilities in learning activities. Besides that the terrain traveledto achieve and distribute aid is very difficult to achieve making the distribution of learning facilities and infrastructure unequal.

2. The number of schools and educational institutions that use multimedia devices which are former educational institutions in rural areas, while still using specifications that are lagging behind with the latest devices so that rural areas will not be able to compete with areas that already fully have the latest multimedia devices.

3. Expensive procurement and use of ICT facilitiesComplicating the above barriers is the overlapping responsibilities between local and national governments in terms of new educational instruments, followed by limited capacity of the general education system and little incentive to appreciate the potential of EdTech products. In addition, Indonesia's underdeveloped consumer protection regulations, particularly those related to data security and privacy, can jeopardize student and school data.

Several options can help overcome this obstacle.

a. The Government of Indonesia can set standards for data privacy and security regarding EdTech products. This has become a major issue in other countries and contributed to a negative reaction to EdTech in some places.

b. EdTech companies can partner with academia and government to set standards for performance and cost-effectiveness, and evaluate some of the leading products in a transparent and rigorous manner. 
c. Governments can continue to invest in improving infrastructure and digital connectivity, particularly in less developed areas and disadvantaged communities.

d. Another important step is to increase potential customers' trust in this new teaching and learning tool, thereby increasing their willingness to pay. This will require further support for the development of EdTech startups, leveraging the support of organizations assisting startups.

e. There is a need for more effective reciprocal interactions between the public and private sectors. Private companies need to better understand the needs of teachers, schools and parents. The government sector needs to clarify its governance structures and promote public-private partnerships for product development.

f. Public education systems can partner with EdTEch companies to improve teachers' ability to deliver technology-focused content. Effective partnerships with EdTech companies can also help public education to update the content of the national curriculum, which deals with technology as well as other topics. These partnerships can also support student learning in times of other crises that limit students' ability to access schools, thereby increasing the resilience of the education system as a whole.

\subsection{Understanding Educational Technology}

The following are some definitions of educational technology:

1 Understanding educational technology according to wikipedia is a study and ethical practice to facilitate and improve learning performance. The study and ethics of such practice can be through the creation, use, regulation of processes, and technological resources. In addition, educational technology can be interpreted as a combination of human elements, machines, ideas, procedures, management. Educational technology is abstract, in this case educational technology can be understood as a complex and integrated process that involves people, procedures, ideas, equipment and organizations to analyze problems, find the best solution to solve problems, implement, assess, manage problem solving. which covers all aspects of human learning (Rahadian, D. 2017).

2 Furthermore, educational technology also has an understanding as a systematic way of designing, implementing, evaluating the overall process of learning and learning in the form of specific learning objectives, based on research in learning theory and communication in humans and using a combination of learning resources from humans and non-humans. -humans to make learning more effective. (Elihami, E., \& Saharuddin, A. (2017)

3 Prof.Dr.Nasution, MA (1987:20) revealed that educational technology is a medium that was born from the development of information tools used for educational purposes. Educational technology is the development, application, and assessment of systems, techniques, and tools to improve and enhance the human learning process (Nurdin, A. 2016).

4 Prof.Dr. Yusuf hardi Miarso, M.Sc (1986:1) explains that educational technology is a complex and integrated process that involves people, procedures, ideas, tools, and organizations to analyze problems and find ways to solve them, implement, evaluate, and manage problem solving. concerns all aspects of human learning. Educational technology is a field of special hope that has an interest in overcoming learning problems in humans, by utilizing various kinds of human and human resources and applying the concept of systems in an effort to solve a problem.

5 At the beginning of the emergence of educational technology (1920), educational technology was seen as a learning media in the form of visuals in the form of pictures, films, and display media in a lesson. Furthermore, in the 1960s educational technology was seen as a way to look at educational problems and examine possible solutions to these problems. Furthermore, in 1970 educational technology has the meaning as a systematic way of designing, implementing and evaluating the overall process of learning and learning in the form of specific learning objectives.

6 In its development, according to AECT, educational technology in 1972 was a field or discipline in facilitating human learning through the identification, development, organization and systematic use of all learning resources and through the management of all of these processes. In 1977 AECT explained that educational technology is a complex integrated process including people, procedures, nested ideas, and organizations to analyze problems and design, implement, assess, and manage problem solving in all aspects of human learning. Furthermore, AECT in 2004 described educational technology as a creative study and practice in an effort to facilitate learning and improve performance by creating, using, or utilize and manage appropriate technological processes and resources. AECT in 2008 provides an understanding of educational technology is a study and ethical practice to 
facilitate learning and improve performance by creating, using, and managing technological processes in accordance with Resources.( Bentri, A., \& Yeni, J. 2012).

7 The axiological basis of educational technology for:

a. Increase education productivity.

b. Clarify in the stages of learning.

c. Helping teachers to make better use of their time.

d. Reducing the burden on teachers in presenting information, providing the possibility of a more individualized education, by way of; reduce rigid and traditional teacher control, provide opportunities for children to develop according to their abilities and provide a more scientific basis for learning.

e. More systematic planning of learning programs.

f. Development of learning materials based on behavioral research.

g. More solidification, by way of: increasing human capacity with various communication media, and presenting information and data more concretely.

h. Allows learning more intimately because it can: reduce the gap between lessons inside and outside school and provide first-hand knowledge.

i. Enabling the presentation of education more broadly and evenly, especially by way of shared utilization of energy or rare events more broadly.

Education and the use of technology allow for a combination of learning media. At the same time, it becomes an opportunity to bring a more complex understanding. For this reason, information technology-based learning media becomes an opportunity for scientific development and also in-depth knowledge. And mastery of adequate skills.

Meanwhile, the use of technology is not only a necessity. But also because of the pandemic. Where the presence of the COVID-19 pandemic has become a necessity in itself. Distance learning that is carried out is easier when using existing technology. This includes information technology which is the pillar of human life today.

\section{Conclusion}

The emergence of educational technology makes it easier for educators and students to learn independently and can create the latest innovations in the world of education so that learning and learning innovations will emerge that make educators and students able to learn easily and fun.

The development of educational technology is also experiencing obstacles in Indonesia itself, the difficulty of the field to distribute and generalize educational technology is still a separate obstacle that has not been able to be resolved, this has resulted in many schools still not having the same multimedia devices as other schools in urban areas so that the delivery of learning materials and the use of learning media is different from those that have multimedia devices that support educational technology. With the Covid-19 pandemic, it demands the government to pay more attention to the interests of education and how students and teachers can learn online, namely by providing free internet access and assistance in the success of the learning activity process where all elements are required to be in harmony and work together to achieve educational goals in the future. this covid-19 pandemic.

\section{Reference}

Arifuddin, A., Wekke, I. S., \& Firdaus, F. (2019). Family and university collaboration: Student guidance practices from the islamic university of alauddin in makassar, indonesia. Internatio

Bahriani, M. M. D. (2020). Pengaruh Pemberian Penguatan (Reinforcement) terhadap Prestasi Belajar Peserta Didik dalam Bidang Studi Pendidikan Agama Islam di SMP Negeri Makassar. Journal Mistar, 1(1).

Bentri, A., \& Yeni, J. (2012). Prosiding Seminar Nasional Teknologi Pendidikan: Optimalisasi Peranan Teknologi Pendidikan dalam Meningkatkan Kualitas Pembelajaran.

Elihami, E., \& Saharuddin, A. (2017). Peran Teknologi Pembelajaran Islam Dalam Organisasi Belajar. Edumaspul: Jurnal Pendidikan, 1(1), 1-8.

Gusty, S., Nurmiati, N., Muliana, M., Sulaiman, O. K., Ginantra, N. L. W. S. R., Manuhutu, M. A., ... \& Warella, S. Y. (2020). Belajar Mandiri: Pembelajaran Daring di Tengah Pandemi Covid-19. Yayasan Kita Menulis.

Kristiawan, M., Yuniarsih, Y., Fitria, H., \& Refika, N. (2019). Supervisi pendidikan. Bandung: Alfabeta. 
Machali, I. (2014). Kebijakan perubahan kurikulum 2013 dalam menyongsong Indonesia emas tahun 2045. Jurnal Pendidikan Islam, 3(1), 71-94.

Mujahid, I., Minsih, M., Ghafur, W. A., \& Wekke, I. S. (2019). Teaching and learning in inclusive classroom; case in elementary school. Journal of Advanced Research in Dynamical and Control Systems, 11(8 Special Issue), 557-568.

Mulyono, M., \& Wekke, I. S. (2018). Academic and culture development strategy management for islamic higher education in indonesian. Paper presented at the IOP Conference Series: Earth and Environmental Science, , 175(1) doi:10.1088/1755-1315/175/1/012163

Musthan, Z., \& Wekke, I. S. (2018). Students' knowledge on various types of research based on problem characteristics at islamic higher education of indonesia. International Journal of Management and Business Research, 8(1), 148-159.

Nurdin, A. (2016). Inovasi pembelajaran pendidikan agama islam di era information and communication Technology. TADRIS: Jurnal Pendidikan Islam, 11(1), 49-64.

Rahadian, D. (2017). Teknologi informasi dan komunikasi (tik) dan kompetensi teknologi pembelajaran untuk pengajaran yang berkualitas. Teknologi Pembelajaran, 2(1).

Suprapno, S., Fadqur, F., Totok, T., Haryanto, H., Hidayatullah, M., Hasan, M., ... \& Muhaemin, M. (2021). Tantangan Pendidikan Di Masa Pandemi Covid-19.

Tanjung, R., Ritonga, T., \& Siregar, E. Y. (2021). Analisis Minat Belajar Siswa Dalam Pembelajaran Daring Pada Masa Pandemi Covid-19 Di Desa Ujung Batu Barus. Jurnal MathEdu (Mathematic Education Journal), 4(1), 88-96.

Taufik, T., \& Warsono, H. (2020). Birokrasi baru untuk new normal: tinjauan model perubahan birokrasi dalam pelayanan publik di era Covid-19. Dialogue: Jurnal Ilmu Administrasi Publik, 2(1), 1-18.

Tukwain, S. M. F., Fatimah, F., \& Wekke, I. S. (2018). Religious expression in coastal area of muslim society west papua. Paper presented at the IOP Conference Series: Earth and Environmental Science, , 156(1) doi:10.1088/1755-1315/156/1/012033

\section{Biographies}

Ismail Suardi Wekke is alecturer at Postgraduate Program in the Department of Islamic Education, State Islamic Institute (IAIN) Sorong, Indonesia, where he serves as chair (2020-2021). Ismail was born in the village namely Camba. A village in Maros Regency, South Sulawesi, Indonesia. Earned his PhD on education at Universiti Kebangsaan Malaysia (2009). Leading Forum Dosen Indonesia DPD West Papua since 2018. Then also joined FORSILADI (2020). Recently, appointed as a visiting professor at Necmenttin Erbakan University, Turkey (September 2021). Among his publications are related to education, human resources, and the environment. His interest in the environment prompted him to pursue degree in environmental engineering (since 2021). His areas of interest and research range in various topics, including teaching and learning, sociolinguistics, and multicultural education.

Muhammad Ihsan, born in Sinjai, South Sulawesi, November 4, 1993. Completed Bachelor (S-1) education at FT Univ. Makassar State in 2015, and Master of Education (S-2) at Univ. Makassar State in 2017. After completing his master's degree he taught as an Extraordinary Lecturer at the Faculty of Engineering, Makassar State University (2017-2018). In 2018 Worked as a permanent lecturer at the foundation at Univ. Sorong Muhammadiyah Education with Homebase Information Technology Education Study Program. As a permanent lecturer, he has also been given the mandate of being Secretary of LPM (2018-2019), in 2019 he became secretary of the Information Technology Education Study Program. In the same year, he was given the mandate as chairman of the Information Technology Education Study Program (2019-2021). During his career several books and articles have been written and published. The article was published in the UNIMUDA Education Journal Sorong and the UNIMUDA Petition Journal Sorong. As a permanent lecturer, he has obtained a functional position as an Expert Assistant.

Muhammad Rusdi Rasyid, Muhammad Rusdi Rasyid who was born in Bulukumba district has successfully completed a doctoral program in Islamic education at UIN Alauddin Makassar. As a lecturer at IAIN Sorong, he was also given the mandate as vice chancellor in the fields of academics, student affairs, institutions and cooperation. Several books and articles have been written and published, including Islamic Education, Development of Islamic Education Perspective of Formal Education, Islamic Moderation Discourse on the Use 
of the Veil at IAIN Sorong, Children's Education in the Perspective of Hadith, Resolution of Maqasid Syariah Against the Covid-19 Virus.

Rudihartono Ismail, is a lecturer at Universitas Amal Ilmiah Yapis Wamena, Indonesia. Earned his doctorate at Universitas Muslim Indonesia. Then, He led the STISIP Amal Ilmiah Yapis Wamena as chairman for two terms. Bringing transformation STISIP Amal Ilmiah Yapis Wamena to university. Get the opportunity to visit various universities including Malaysia, and Thailand. Become the general chairman of ICMI Wamena. As a scientific committee conference for ICETES (2019) ADRI International Conference (2019). Writes books related to the land of Papua, Yapis, and human resource development. His interest in geography, environment, brought him to international association related to higher education, environment, and human resources.

M. Makbul, a teacher of Islamic Religious Education at the 5 Makassar State Senior High School, as well as a lecturer at the DDI Islamic College of Makassar City, and now continuing his doctoral education at the Alauddin State Islamic University of Makassar. Makbul was born in Baraka, Enrekang, South Sulawesi, Indonesia. His field of interest and research concentration is currently focused on issues of education, teacher training and religious education, and sometimes also discusses research methods. Currently Makbul is broadening his experience at the Himpunan Mahasiswa Islam, PEDANA Institute, Elstudika Indonesia, managing journals, writing articles, researching and studying. 